\title{
CONSTRUCTION OF AN ULTRASONIC TOMOGRAPH FOR ANALYSIS OF TECHNOLOGICAL PROCESSES IN THE FIELD OF REFLECTION AND TRANSMISSION WAVES
}

\author{
Tomasz Rymarczyk ${ }^{1,2}$, Michał Gołąbek ${ }^{1}$, Piotr Lesiak ${ }^{2}$, Andrzej Marciniak ${ }^{2}$, Mirosław Guzik ${ }^{2}$ \\ ${ }^{1}$ Research and Development Center, Netrix S.A., Lublin, Poland, ${ }^{2}$ University of Economics and Innovation in Lublin, Lublin, Poland
}

Abstract. This article presents the ultrasonic structure for the analysis of technological processes in the field of reflective and transmission waves. Ultrasound tomography enables the analysis of processes occurring in the examined object without interfering with its interior through appropriate acquisition and analysis of data. The design goal is to verify the repeatability of measurement results by eliminating laboratory equipment. The ultrasonic tomograph has been designed in a modular way and consists of a motherboard connected to an analog signal conditioning board, a liquid crystal display with an integrated graphics processor and a high voltage pulser with a 64 channel multiplexer. The solution was designed for tomographic measurements of technological process properties.

Keywords: ultrasound tomography, sensors, measurements

\section{BUDOWA TOMOGRAFU ULTRADŹWIĘKOWEGO DO ANALIZY PROCESÓW TECHNOLOGICZNYCH W ZAKRESIE FAL ODBITYCH I TRANSMISYJNYCH}

Streszczenie. W niniejszym artykule przedstawiono konstrukcję tomografu ultradźwiękowego do analizy procesów technologicznych w zakresie fal odbitych $i$ transmisyjnych. Tomografia ultradźwiękowa umożliwia analizowanie procesów zachodzacych w badanym obiekcie bez ingerencji w jego wnętrze poprzez odpowiednia akwizycję $i$ analizę danych. Celem konstrukcyjnym jest weryfikacja powtarzalności wyników badań pomiarowych poprzez wyeliminowanie sprzętu laboratoryjnego. Tomograf ultradźwiękowy zostat zaprojektowany $w$ sposób modułowy $i$ składa się z plyty głównej połaczonej z płyta kondycjonowania sygnatu analogowego, wyświetlacza ciektokrystalicznego ze zintegrowanym procesorem graficznym oraz impulsatora wysokiego napięcia wraz z 64 kanałowym multiplekserem. Urządzenie zostało zaprojektowane do tomograficznych pomiarów właściwości procesów technologicznych.

Słowa kluczowe: tomografia ultradźwiękowa, sensory, pomiary

\section{Introduction}

Ultrasound tomography can be used to analyze the processes taking place in the facility without interfering with the production, analysis or detection of obstacles, defects and various anomalies. The article describes the measuring system has a specially designed measuring structure. The application allows you to choose the right method of image reconstruction thanks to knowledge of the features of each solution. The process of identifying optimization or synthesis, in which the goal is to specify parameters describing the data field, is solved by the inverse problem. The designed system for data acquisition and analysis enables monitoring and control of technological processes related to the processing of data obtained from various sensors. The idea of measuring in ultrasonic tomography is shown in Fig. 1.

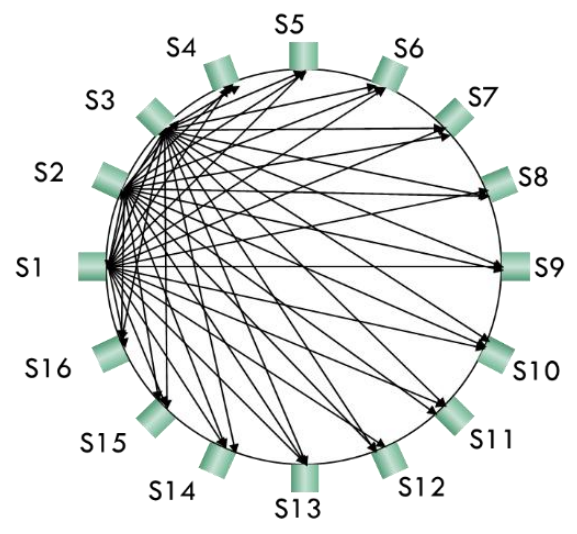

Fig. 1. The principle of ultrasonic measurement by transmission mode

Measuring technologies are still being improved. There is a clear tendency to implement more optimal solutions with an emphasis on active control and optimization [11-15, 25-27]. There are many numerical methods $[1-4,17,24,28,29]$, but in order to solve the inverse problem, ultrasound tomography [5-10, 16] can be used.

The principle of operation is that one of the active probes sends an ultrasonic signal, the other probes are in the receiving mode. The number of signal periods sent will depend on the type and size of the object being tested. For the container tested, four periods are sufficient. Active probes measure time individually from the moment the signal is sent to when it is picked up by individual transducers. This is the time when ultrasound travels the distance between probes.

\section{Measurement system}

The reflective ultrasound tomograph has been designed in a modular way (Fig. 2-4). The first module consists of a motherboard connected to an analog signal conditioning board and a liquid crystal display with an integrated FT811CB graphics processor. The second module consists of a high voltage pulse generator with a 64-channel multiplexer.

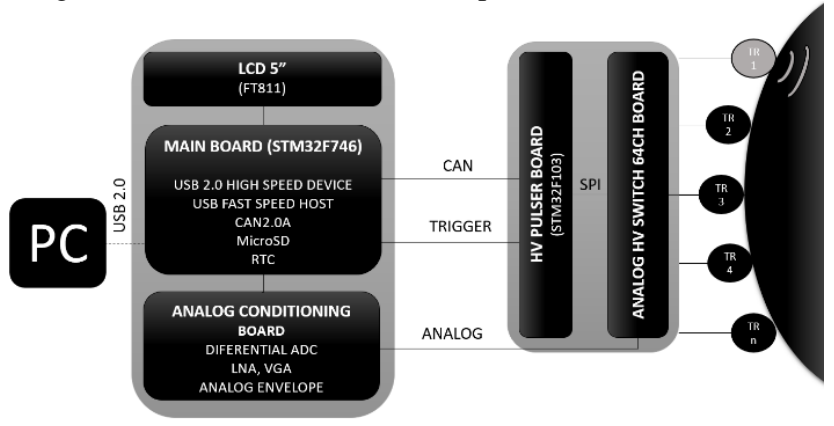

Fig. 2. Block diagram of an ultrasonic reflective tomograph

When designing the main module of the device, great emphasis was placed on its universality. The size of the printed circuit board depends on the dimensions of the FT811CB display. The main module board itself will be mounted under the display. The board allows you to connect external storage media: micro SD cards, portable drives to the USB Fast Speed port. The board has a spare RTC battery, spare registers, EEPROM memory. Communication with the computer can be implemented in the USB High Speed 2.0 standard. The debugger connector and serial port are connected. CAN, SPI, RS485 buses are output via the standard Cat 6 a connector. Other I/O ports come from popular terminal blocks. 


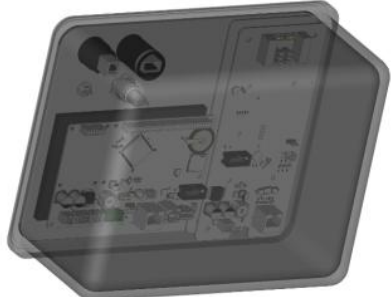

Fig. 3. Device model

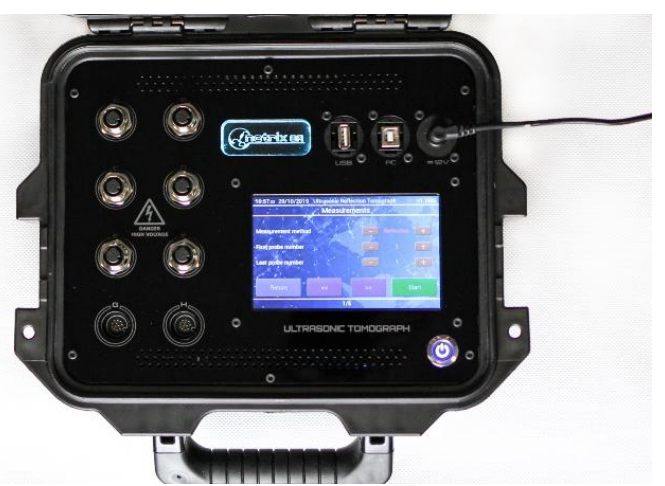

Fig. 4. Ultrasound tomograph

The device is a closed structure that needs several control signals:

- CAN 2.0A bus

Setting device parameters such as:

- Channel number to which the extortion is given,

- Channel number from which the analogue signal is fed to the $\mathrm{A} / \mathrm{C}$ converter,

- The number of pulses generated,

- Frequency of pulses generated,

- Time of output shorting to ground after keying,

- Brightness levels of RGB channels with backlit company logo.

- TRIGGER

This is a differential signal that triggers the bipolar excitation signal generator.

- ANALOG

The analog signal output from the multiplexer is protected by a high voltage cut-off system.

To generate waveforms to control the MOSFET key, use three cascade-connected hardware counters operating in One Pulse mode. In Figure 5 the exact way to connect the counters. The generator cycle begins by receiving a signal at the differential input of the TRIGGER line, which generates an interruption in the microcontroller during the execution of the ENA-BLE line is set to high, and also TIM1 is started (OUTA, OUTB), after the TIM1 countdown, the hardware called TIM 2 , the countdown for the first

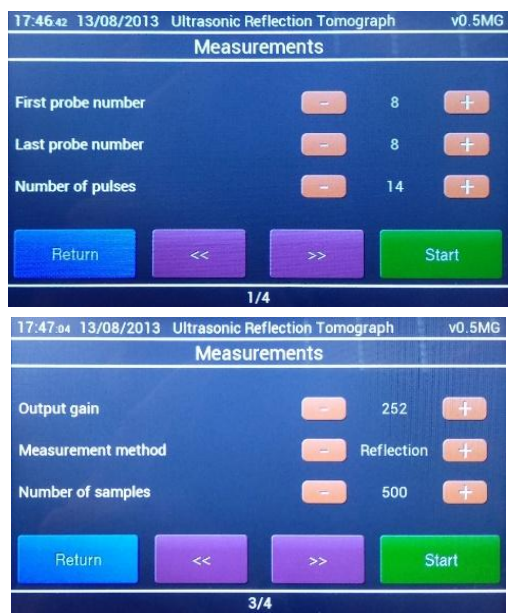

counting period, after which the equipment sets the low state on OUTA, OUTB lines and starts TIM3. The third timer counts down the time by one TX output is topped with something that starts the interrupted program statement of the ENABLE line in the low state. Which causes MD1822 to set up secure tables on MOSFET TC8220 high-voltage key exchange control lines.

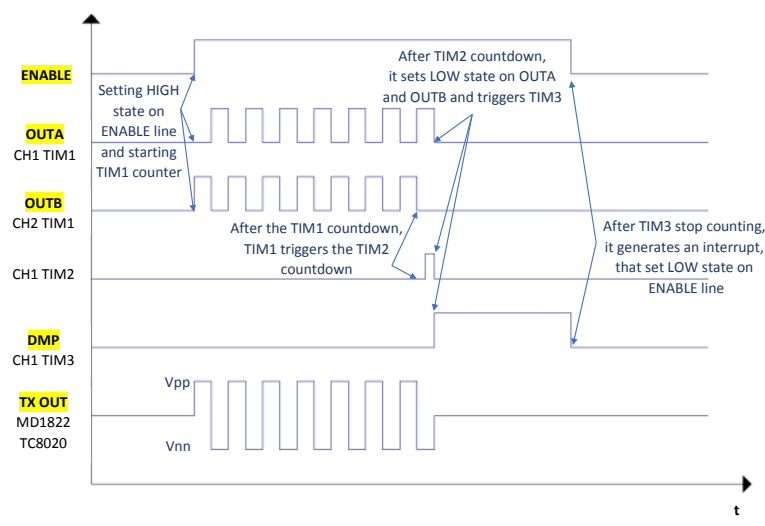

Fig. 5. MOSFET key control method for high voltage generator

\section{User interface}

Tomography software, including the user interface at the current stage of work is still being developed. The screenshots below are illustrative (Fig. 6).

Measuring parameters that can be changed:

- First probe number - the number of the probe from which the measurement sequence begins,

- Last probe number - the probe number at which the measurement sequence ends,

- Number of pulses - the number of bipolar pulses generated by the excitation system,

- Short to ground after transmission - the time for which the excitation system closes the ground lines after the transmission,

- Frequency - the frequency of the excitation signal,

- Input gain - amplification of the first stage of signal processing (12 bit)

- Output gain - amplification of the second stage of signal processing (signal envelope path, 8 bit),

- Measurement method - a method of performing measurements: reflection / transmission,

- Number of samples - the number of samples collected by the analog to digital converter,

- Sampling [ns] - signal sampling,

- A/D converter selection - selection of $\mathrm{a} / \mathrm{c}$ converter (measurement of signal envelope or measurement of unprocessed signal).

The START button starts the measurement cycle during which data is sent via USB to the computer in binary form.

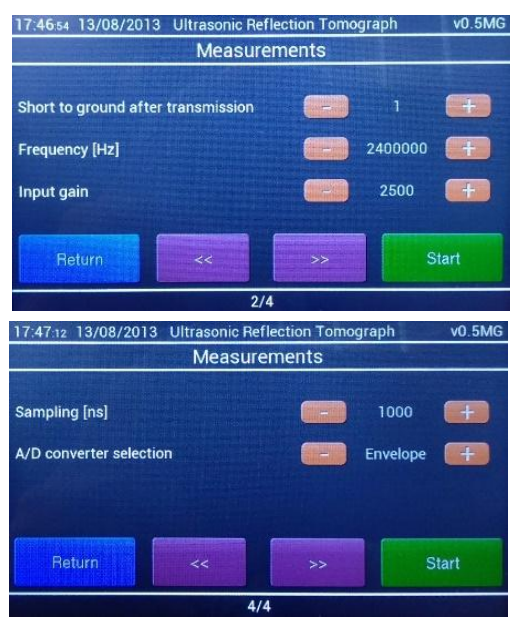




\section{Measurement tests}

Measurements were made using 8 ultrasonic probes designed in the laboratory. The probes made by us work with a resonance frequency of $2.4 \mathrm{MHz}$. Due to the low resonance impedance of the transducers (approx. $2 \mathrm{Ohm}$ ), each probe has a $49 \mathrm{Ohm}$ series resistor protecting the tomograph against damage. The ultrasonic transducers used, depending on the specimen, show varying sensitivity to signal reflections (Fig. 7)

The measurements were carried out in a plastic vessel with a diameter of $34 \mathrm{~cm}$ with full immersion of the sensor in water, a plastic bottle filled with water was used as a phantom (Fig. 8).

Tomograph settings:

- Number of pulses: 16 ,

- First level strengthening: 2332/4095,

- Second degree gain (envelope): 252/255,

- Measurement method: reflective,

- Number of samples: 500,

- Sampling: 1 us.

\section{Sensor 1}
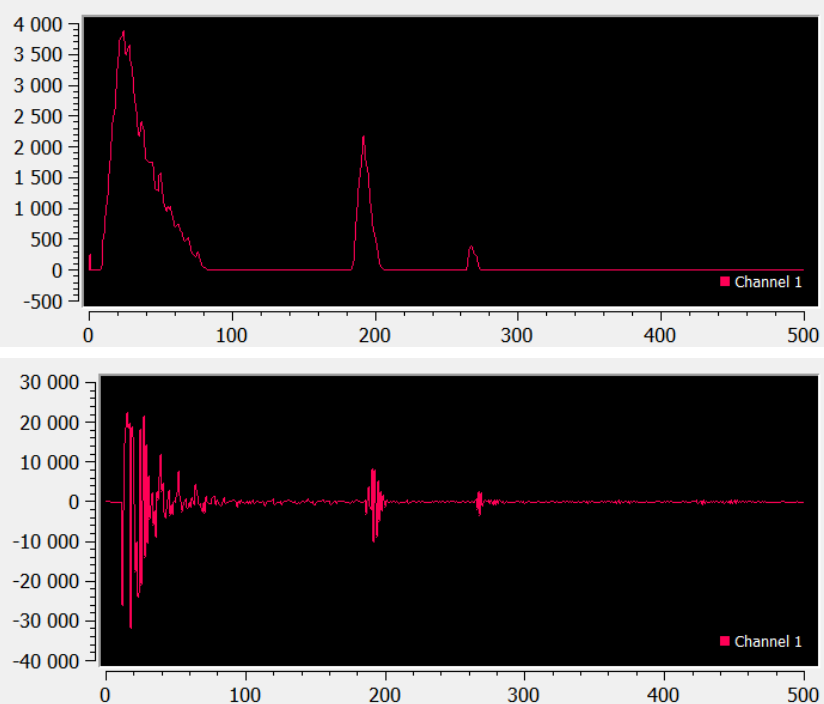

$\underline{\text { Sensor } 2}$
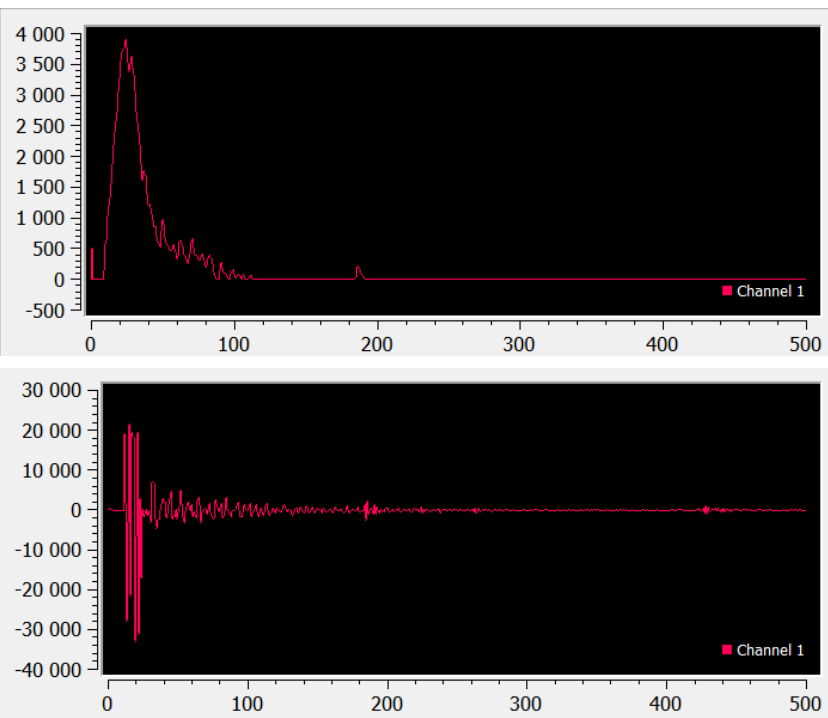

Fig. 9 (part 1). Waveforms for each probe and for comparison waveforms captured without processing into boundaries

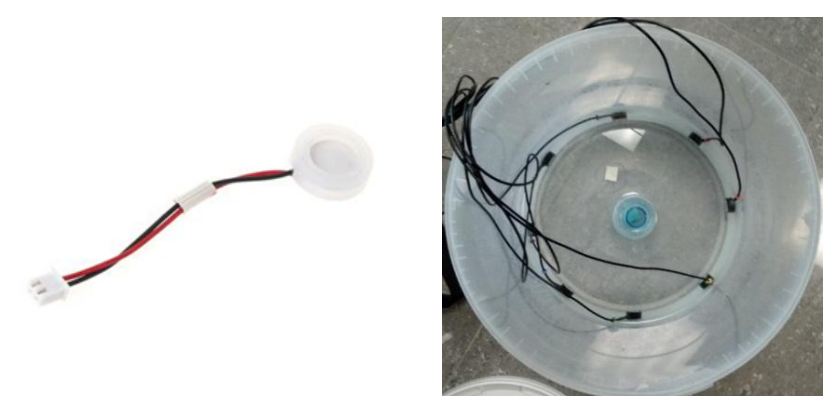

Fig. 7. Ultrasonic probe

Fig. 8. Measuring object

The captured waveforms for each of the probes are shown below, and for comparison the waveforms captured without converting to boundaries (Fig. 9). From the measurements it is possible to observe a very high wave direction at such a high frequency. For example, the same bottle slightly tilted would not be visible through all probes, because the wave reflected from it directly would not return back to the inverter.

\section{$\underline{\text { Sensor } 3}$}
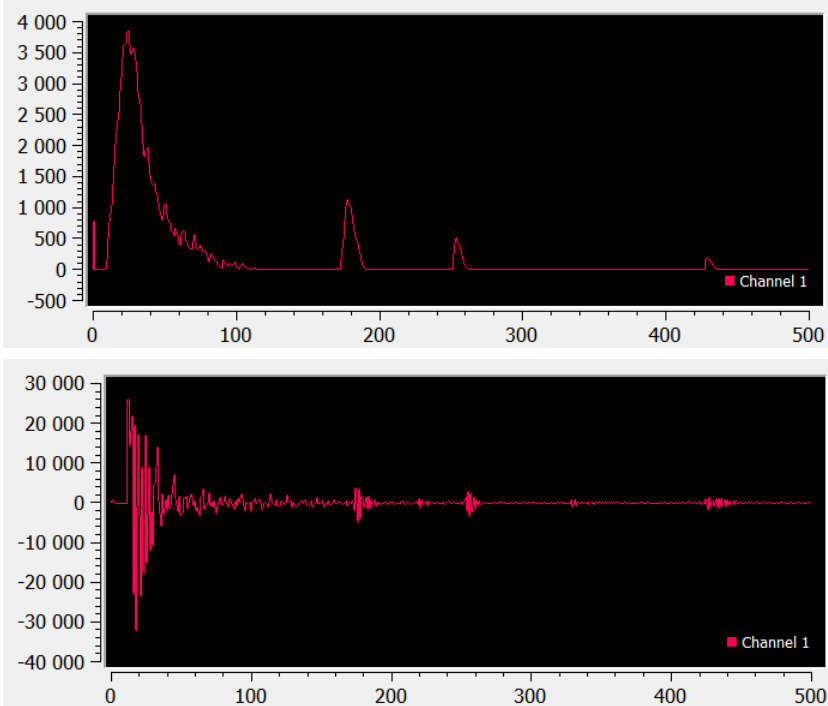

Sensor 4
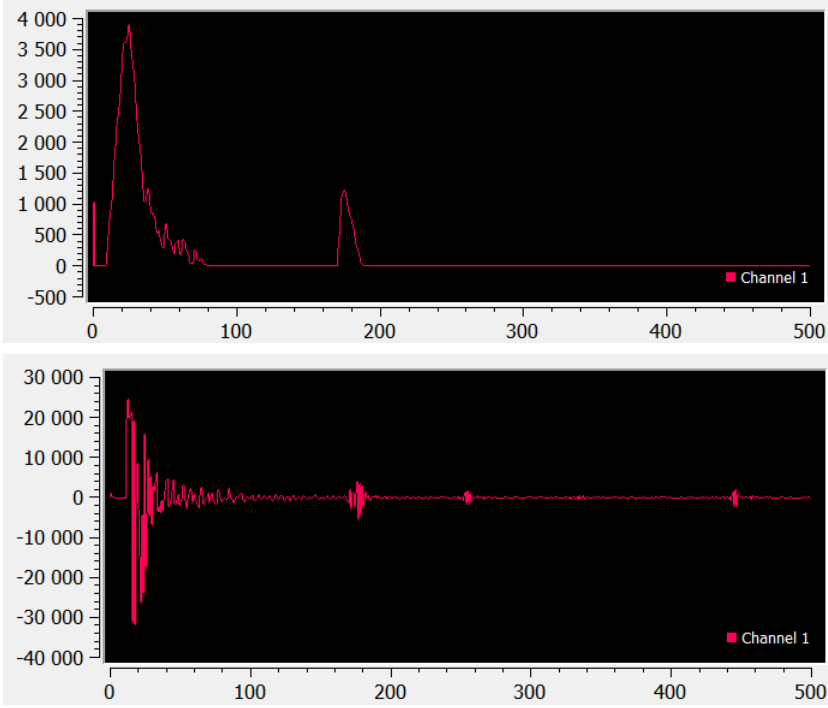


\section{Sensor 5}
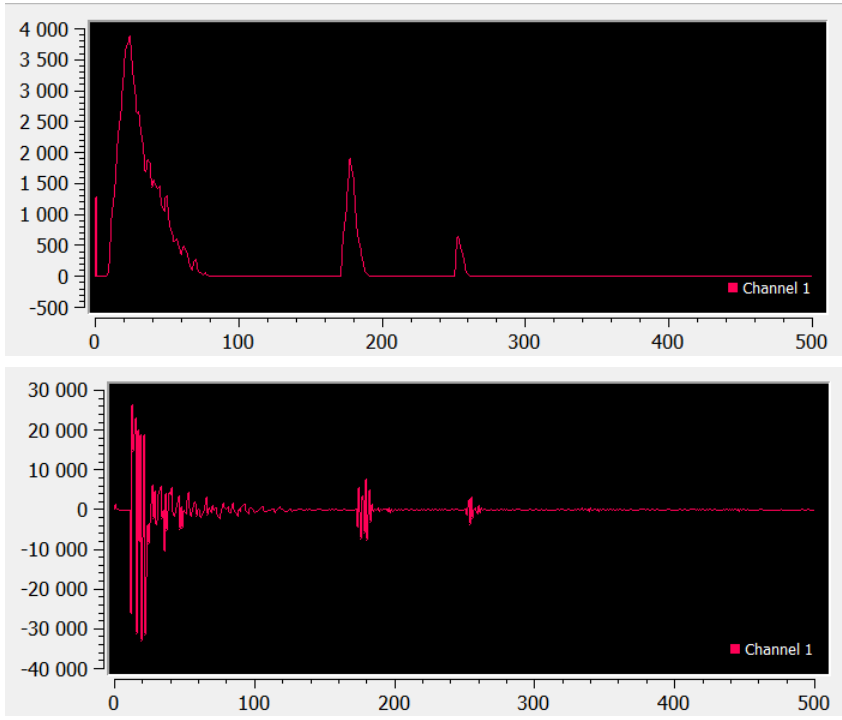

\section{$\underline{\text { Sensor } 6}$}
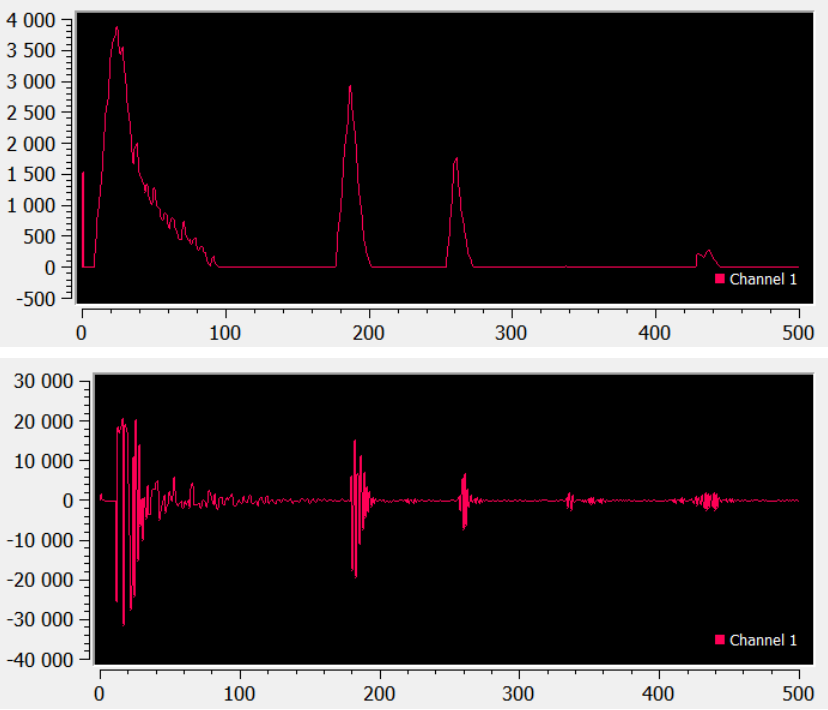

Fig. 9 (part 2). Waveforms for each probe and for comparison waveforms captured without processing into boundaries

\section{Conclusion}

The article presents the construction of the device based on ultrasonic tomography. An original tomograph was designed for measuring ultrasonic waves and processing data obtained from various sensors. The ultrasonic tomograph has been designed in a modular way and consists of a motherboard connected to an analogue signal conditioning board, a liquid crystal display with an integrated graphics processor and a high voltage pulser with a 64 channel multiplexer. The device allows you to analyse the properties of various technological processes. Measurements were carried out in a plastic vessel with the sensor fully immersed in water, a plastic bottle filled with water was used as a phantom. Waveforms for each of the probes are presented and for comparison waveforms captured without processing into boundaries, where very high directionality of the wave can be observed at such a high frequency.

\section{References}

[1] Babout L., Grudzień K., Wiącek J., Niedostatkiewicz M., Karpiński B., Szkodo M.: Selection of material for X-ray tomography analysis and DEM simulations: comparison between granular materials of biological and nonbiological origins. Granul. Matter 20(3)/2018, 38

\section{Sensor 7}
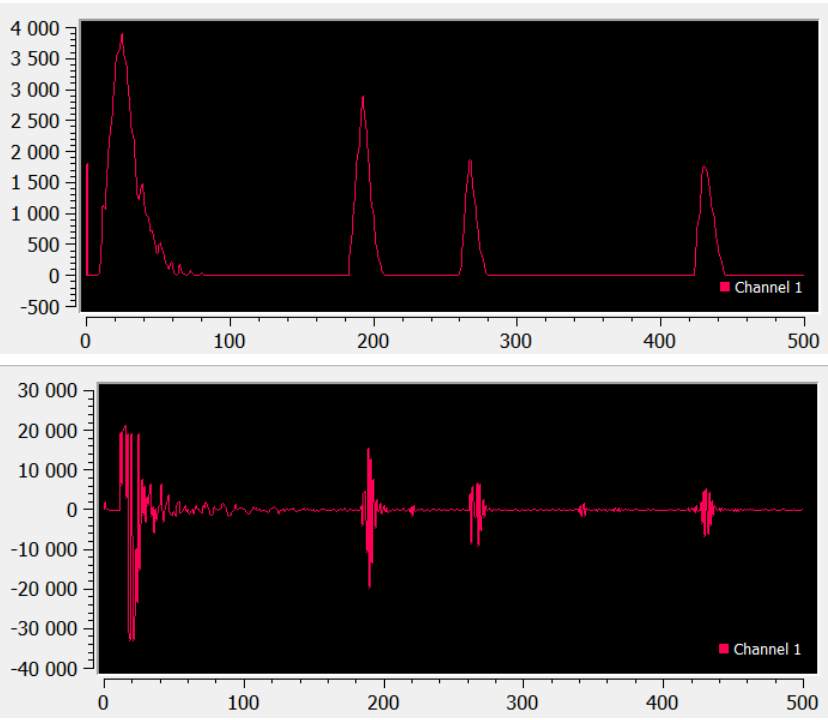

\section{$\underline{\text { Sensor } 8}$}
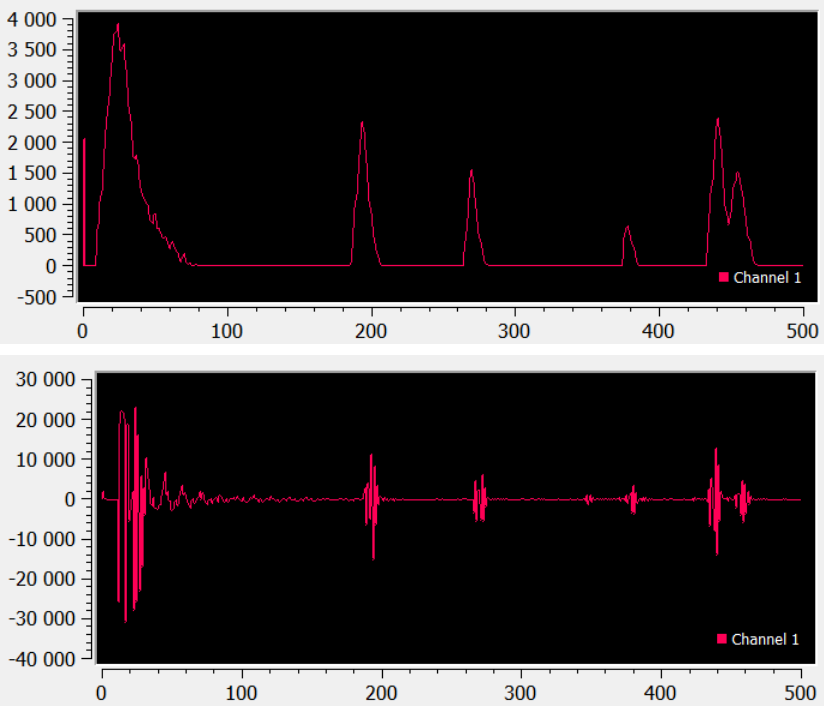

[2] Chaniecki Z., Romanowski A., Nowakowski J., Niedostatkiewicz M. Application of twin-plane ECT sensor for identification of the internal imperfections inside concrete beams Grudzien. IEEE Instrumentation and Measurement Technology Conference 2016, 7520512.

[3] Duda K., Adamkiewicz P., Rymarczyk T., Niderla K.: Nondestructive Method to Examine Brick Wall Dampness. International Interdisciplinary $\mathrm{PhD}$ Workshop, Brno, 2016, 68-71.

[4] Fiala P., Drexler P., Nešpor D., Szabó Z., Mikulka J., Polívka J.: The Evaluation of Noise Spectroscopy Tests. Entropy 18(12)/2016, 1-16.

[5] Gudra T., Opieliński K. J.: The multi-element probes for ultrasound transmission tomography. Journal de Physique 4(137)/2006, 79-86.

[6] Golabek M., Rymarczyk T., Adamkiewicz P.: Construction of ultrasonic reflection tomograph for analysis of technological processes, Applications of Electromagnetics in Modern Engineering and Medicine. XXIX Sympozjum PTZE 2019, 47-51.

[7] Herman G.T.: Image Reconstruction from Projections: The Fundamentals of Computerized Tomography. Academic Press, New York 1980.

[8] Jiang Y., Soleimani M., Wang B.: Contactless electrical impedance and ultrasonic tomography, correlation, comparison and complementary study. Measurement Science and Technology 30/2019, 114001.

[9] Kaczmarz S.: Angenäherte Auflösung von Systemen Linearer Gleichungen. Bull. Acad. Polon. Sci. Lett. A, 6-8A/1937, 355-357.

[10] Kak A. C., Slaney M.: Principles of Computerized Tomographic Imaging. IEEE Press, New York 1999

[11] Kryszyn J., Wanta D. M., Smolik W. T.: Gain Adjustment for Signal-to-Noise Ratio Improvement in Electrical Capacitance Tomography System EVT4. IEEE Sens. J. 17(24)/2017, 8107-8116.

[12] Kryszyn J., Smolik W.: Toolbox for 3d modelling and image reconstruction in electrical capacitance tomography. Informatyka, Automatyka, Pomiary w Gospodarce i Ochronie Środowiska - IAPGOŚ 7(1)/2017, 137-145. 
[13] Lopato P., Chady T., Sikora R., Ziolkowski M.: Full wave numerical modelling of terahertz systems for nondestructive evaluation of dielectric structures COMPEL - The international journal for computation and mathematics in electrical and electronic engineering 32(3)/2013, 736-749.

[14] Majchrowicz M., Kapusta P., Jackowska-Strumiłło L., Sankowski D. Optimization of Distributed Multi-node, Multi-GPU, Heterogeneous System for 3D Image Reconstruction in Electrical Capacitance Tomography. Image processing \& communications 21(3)/2016, 81-90.

[15] Nowakowski J., Ostalczyk, P., Sankowski D.: Application of fractional calculus for modelling of two-phase gas/liquid flow system. Informatyka, Automatyka, Pomiary w Gospodarce i Ochronie Srodowiska - IAPGOS 7(1)/2017, 42-45.

[16] Polakowski K., Sikora J.: Podstawy matematyczne obrazowania ultradźwiękowego. Politechnika Lubelska, Lublin 2016.

[17] Romanowski A., Łuczak P., Grudzień K.: X-ray Imaging Analysis of Silo Flow Parameters Based on Trace Particles Using Targeted Crowdsourcing. Sensors $19(15) / 2019,3317$

[18] Rymarczyk T., Kłosowski G.: Innovative methods of neural reconstruction for tomographic images in maintenance of tank industrial reactors. Eksploatacja $\mathrm{i}$ Niezawodność - Maintenance and Reliability 21(2)/2019, 261-267.

[19] Rymarczyk T., Filipowicz S. F., Sikora J.: Level Set Method for Inverse Problem Solution In Electrical Impedance Tomography. Journal Proceedings of the XII International Conference on Electrical Bioimpedance \& V Electrical Impedance Tomography, 2004, 519-522.

[20] Rymarczyk T., Kozłowski E., Kłosowski G., Niderla K.: Logistic Regression for Machine Learning in Process Tomography. Sensors 19/2019, 3400.

[21] Rymarczyk T., Szumowski K., Adamkiewicz P., Tchórzewski P., Sikora J. Moisture Wall Inspection Using Electrical Tomography Measurements. Przegląd Elektrotechniczny 94/2018, 97-100.

[22] Rymarczyk T., Nita P., Vejar A., Stefaniak B., Sikora J.: Electrical tomography system for Innovative Imaging and Signal Analysis. Przeglad Elektrotechniczny 95(6)/2019, 133-136

[23] Soleimani M., Mitchell C. N., Banasiak R., Wajman R., Adler A.: Fourdimensional electrical capacitance tomography imaging using experimental data. Progress in Electromagnetics Research 90/2009, 171-186.

[24] Szczęsny A., Korzeniewska E.: Selection of the method for the earthing resistance measurement. Przegląd Elektrotechniczny 94(12)/2018, 178-181.

[25] Vališ D., Hasilová K., Forbelská M., Vintr Z.: Reliability modelling and analysis of water distribution network based on backpropagation recursive processes with real field data. Measurement 149/2020, 107026

[26] Wajman R., Fiderek P., Fidos H., Sankowski D., Banasiak R.: Metrologica evaluation of a $3 \mathrm{D}$ electrical capacitance tomography measurement system for two-phase flow fraction determination. Measurement Science and Technology 24(6)/2013, 065302

[27] Wang M.: Industrial Tomography: Systems and Applications. Elsevier 2015.

[28] Ye Z., Banasiak R., Soleimani M.: Planar array 3D electrical capacitance tomography. Insight: Non-Destructive Testing and Condition Monitoring 55(12)/2013, 675-680.

[29] Ziolkowski M., Gratkowski S., Zywica A. R.: Analytical and numerical model of the magnetoacoustic tomography with magnetic induction. COMPEL - The international journal for computation and mathematics in electrical an electronic engineering 37(2)/2018, 538-548.
Ph.D. Eng. Tomasz Rymarczyk

e-mail: tomasz@rymarczyk.com

$\mathrm{He}$ is the director in Research and Development Centre in Netrix S.A. and the director of the Institute of Computer Science and Innovative Technologies in the University of Economics and Innovation, Lublin, Poland.. He worked in many companies and institute developing innovative projects and managing teams of employees. His research area focuses on the application of non-invasive imaging techniques, electrical tomography, image reconstruction, numerical modelling, image processing and analysis, process tomography, software engineering, knowledge engineering, artificial intelligence and computer measurement systems.

ORCID ID: 0000-0002-3524-9151

\section{M.Sc. Eng. Michal Goląbek}

e-mail: michal.golabek@netrix.com.pl

He is embedded software developer and electrical engineer employed in Research and Development Department of Netrix S.A. Currently he is working on ultrasound tomography project. He graduated with Master of Engineering in Electrical Engineering with specialization "Microprocessor drives in industrial automation" on Lublin University of Technology.

ORCID ID: 0000-0002-2696-505X

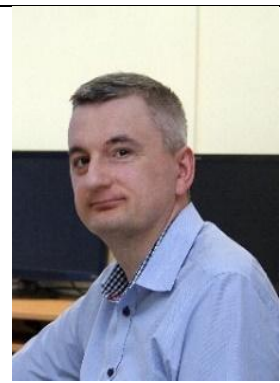

D.Sc. Eng. Piotr Lesiak

e-mail: piotr.lesiak@wsei.lublin.pl

The Faculty of Transport and Computer Science, University of Economics and Innovation in Lublin. His research interests include technical diagnostics and smart systems measurements in railway transport.

ORCID ID: 0000-0002-9792-3463

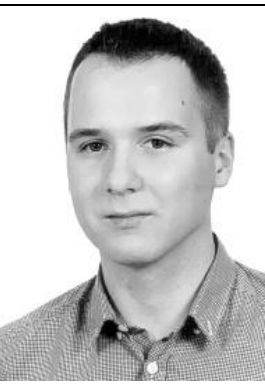

D.Sc. Eng. Andrzej Marciniak e-mail: andrzej.marciniak@wsei.lublin.pl

The Faculty of Transport and Computer Science, University of Economics and Innovation in Lublin. His research interests include data analysis, graph

databases and machine learning methods.

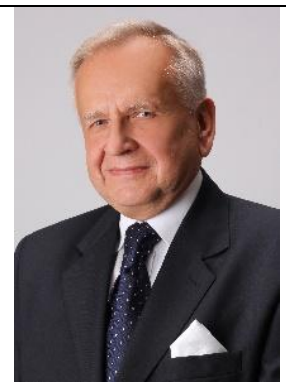

ORCID ID: 0000-0002-2718-4802

\section{Ph.D. Eng. Mirosław Guzik}

e-mail: miroslaw.guzik@wsei.lublin.pl

The Faculty of Transport and Computer Science, University of Economics and Innovation in Lublin. His research interests include reverse enginneering, rapid prototyping and $3 \mathrm{D}$ systems measurements in mechanical engineering.

ORCID ID: 0000-0003-3351-9039
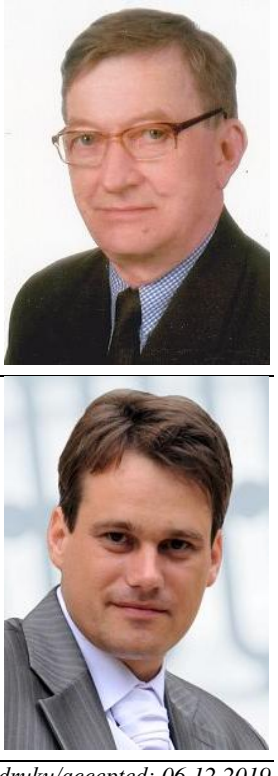